\title{
Find the right sample: A study on the versatility of saliva and urine samples for the diagnosis of emerging viruses
}

\author{
Matthias Niedrig $^{\text {* }^{*} \text {, Pranav Patel }}{ }^{2}$, Ahmed Abd El Wahed ${ }^{3}$, Regina Schädler ${ }^{1}$ and Sergio Yactayo ${ }^{4}$
}

\begin{abstract}
Background: The emergence of different viral infections during the last decades like dengue, West Nile, SARS, chikungunya, MERS-CoV, Ebola, Zika and Yellow Fever raised some questions on quickness and reliability of laboratory diagnostic tests for verification of suspected cases. Since sampling of blood requires medically trained personal and comprises some risks for the patient as well as for the health care personal, the sampling by noninvasive methods (e.g. saliva and/ or urine) might be a very valuable alternative for investigating a diseased patient.

Main body: To analyse the usefulness of alternative noninvasive samples for the diagnosis of emerging infectious viral diseases, a literature search was performed on PubMed for alternative sampling for these viral infections. In total, 711 papers of potential relevance were found, of which we have included 128 in this review.

Conclusions: Considering the experience using non-invasive sampling for the diagnostic of emerging viral diseases, it seems important to perform an investigation using alternative samples for routine diagnostics. Moreover, during an outbreak situation, evaluation of appropriate sampling and further processing for laboratory analysis on various diagnostic platforms are very crucial. This will help to achieve optimal diagnostic results for a good and reliable case identification.
\end{abstract}

Keywords: Sample type, Emerging diseases, Viruses, Diagnostics

\section{Background}

The emergence of several virus infections during the last decades like dengue, West Nile (WN), Severe acute respiratory syndrome (SARS), chikungunya (CHIK), Middle East respiratory syndrome coronavirus (MERS-CoV), Ebola (EBO), Zika (ZIK) and Yellow Fever (YF) raised some questions on quickness and reliability of laboratory diagnostic tests for verification of suspected cases. All important questions arising with an emerging infection like source and route of transmission, infectivity of patients, recommendation of safety measures for health care personal and distribution in an animal reservoir or other vectors require the performance of laboratory diagnosis. To investigate the patient's infections most often a blood sample is taken not only for the analysis of blood parameters but also for pathogen detection mostly

\footnotetext{
* Correspondence: niedrigm@gmx.de; niedrigm@rki.de

${ }^{1}$ Robert Koch Institute, Berlin, Germany

Full list of author information is available at the end of the article
}

by PCR or for testing the presence of specific antibodies. However, sampling of blood requires medically trained personal and comprises some risks for the patient as well as for the health care personal. In particular the blood sampling of patients with highly infectious haemorrhagic fever like Ebola involve a great risk for the physician and the patient. Therefore, the sampling by non-invasive methods (e.g. saliva and/ or urine) might be a very valuable alternative for investigating a diseased patient. The use of saliva and urine for the diagnosis for many viral infections has been reported, however, it is often not performed in the broad routine diagnostics.

After a viral infection it usually takes some days until the propagation of the virus causes symptoms and a clinical investigation of a patient is indicated. Blood sampling for analysing blood parameters belongs to a routine procedure in developed countries. This is different in developing countries, where extensive analyses of clinical parameters are not performed routinely due to financial and technical constraints. Even though the

(c) The Author(s). 2018 Open Access This article is distributed under the terms of the Creative Commons Attribution 4.0 International License (http://creativecommons.org/licenses/by/4.0/), which permits unrestricted use, distribution, and reproduction in any medium, provided you give appropriate credit to the original author(s) and the source, provide a link to the Creative Commons license, and indicate if changes were made. The Creative Commons Public Domain Dedication waiver (http://creativecommons.org/publicdomain/zero/1.0/) applies to the data made available in this article, unless otherwise stated. 
sampling of swaps from the respiratory tracks is a common procedure for influenza, SARS, MERS-CoV and other respiratory infections, the sampling of blood is the prevalent procedure for all other recently emerged viruses. However, with the introduction of the highly sensitive Nucleic Acid Tests (NAT) for diagnostic also additional samples like saliva and/or urine were included in diagnostic sample collections. The advantage of using non-invasive samples like saliva for dengue serology was successfully proven 18 years ago by Cuzzubbo et al. who discovered that dengue primary and secondary infections can be distinguished by the level of IgG in saliva [1]. The specificity of the diagnosis of acute flavivirus infections like dengue, WN and YF has been improved by applying the NAT because it is not impeded by the widespread cross-reactivity found for most serological assays [2]. Since urine, saliva and other non-invasive samples were not part of the routine investigation, the sampling procedures and the samples containment are also very different. These differences complicate the interpretation of diagnostic findings and therefore an optimization for these samplings is required. An improvement of the sampling and stabilization of viral RNA in the diagnostic material will help to increase significantly the diagnostic sensitivity.

To analyse the usefulness of alternative non-invasive samples for diagnostic of infectious viral diseases like SARS, WN, dengue, MERS-CoV, Ebola, Zika and YF, we reviewed the importance of saliva and urine for the diagnosis of recently emerging viruses in comparison to conventional blood sampling. Since the extensive evaluation of different samples for human patients is often not performed, also investigations of animal models or vectors are considered. Therefore, we performed an electronic literature review on PubMed for alternative sampling for SARS, WN, dengue, MERS-CoV, Ebola, Zika and YF.

\section{Main text \\ Method of literature search}

A review of the literature for urine and saliva samples for diagnostic of CHIK, dengue, Ebola, WN, Zika, YF, SARS and MERS was performed using the electronic database PubMed. The period for searches was $1^{\text {st }}$ January $1980-26^{\text {th }}$ August 2016.

Appropriate articles were selected according to their abstracts and further reviewed for reason for diagnostic analysis, sample types used and the methods applied for diagnosis focusing on saliva and urine as test samples.

Search profile used for this review in PubMed for CHIK as an example:

"chikungunya virus"[MeSH Terms] OR ("chikungunya"[All Fields] AND "virus"[All Fields]) OR "chikungunya virus"[All Fields] AND ("saliva"[MeSH Terms] OR "saliva"[All Fields]) "chikungunya virus"[MeSH Terms] OR ("chikungunya"[All Fields] AND "virus"[All Fields]) OR "chikungunya virus"[All Fields] AND ("urine"[Subheading] OR "urine"[All Fields] OR "urine"[MeSH Terms])

Another 42 references were considered for analysing the preparation and storage of diagnostic samples as demonstrated in Table 1, see Additional file 1 for detailed methodology.

The literature research revealed 711 papers, of which we considered 128 in this study (Additional file 1: Figure S1). Furthermore 43 publication analysing the sample processing and preparation were included.

Our analysis shows that there should be put more emphasis on non-invasive sampling to disclose more easy alternatives for collecting human samples for clinical and routine investigations. The present review provides some indications that non-invasive sampling offers a promising alternative for routine diagnostic as well as a favourable diagnostic approach for surveillance studies with high numbers of samples. The review provides an overview of the usability of non-invasive sample for diagnostics of emerging viruses and tries to give recommendation on how this experience could be helpful for future possible outbreaks of emerging viruses.

\section{Chikungunya}

After an epidemic at La Reunion in 2005, an autochthone outbreak in Italy in 2007 and, spread in Caribbean islands in December 2013, chikungunya (CHIK) emerged in 2014 for the first time in Central America spreading into South America and North America [3-7]. Typical clinical specimens for CHIKV are blood, serum and plasma, but also urine, saliva and in rare cases CSF (Table 1, Additional file 1: Table S1). A systematic evaluation of the CHIK infection in mice and Cynomolgus macaques revealed the infectivity of different body fluids like saliva, urine and vaginal swaps [8]. This could be confirmed by analysis of saliva samples from 4 out of 13 acute CHIKV patients with haemorrhagic manifestations, which were found to contain viral RNA and infectious virus. Another study shows that RNA of chikungunya virus can be detected in the saliva at the first seven days of infection but with a lower efficacy than blood samples [9]. Also the detection of CHIKV genome by RT-PCR in urine was successful in one returning traveller, which is a valuable confirmation of the positive serology [10]. Based on the experience with other viral infections, the analysis of throat swabs and urine are part of recommendation for CHIK diagnostic [11].

\section{Dengue}

Common clinical specimens used for dengue infection are blood, plasma and serum, but also in some cases CSF and breast milk (Table 1, Additional file 1: Table 
Table 1 Overview of selected publications describing samples used for viral diagnostic

\begin{tabular}{|c|c|c|c|c|c|c|c|c|c|}
\hline \multirow[t]{2}{*}{ Type of specimens } & & \multicolumn{5}{|c|}{ Arboviruses } & \multirow{2}{*}{$\begin{array}{l}\text { VHFV } \\
\text { EBOV }\end{array}$} & \multicolumn{2}{|c|}{ Coronaviruses } \\
\hline & & $\mathrm{CHIKV}$ & DENV & WNV & YFV & ZIKV & & SARS & MERS \\
\hline \multirow[t]{5}{*}{ Blood derived samples } & whole blood & [139] & [143] & {$[147,148]$} & n.r. & {$[88]$} & [160] & [165] & [170] \\
\hline & peripheral blood (cells) & [139] & [144] & {$[147,148]$} & n.r. & n.r. & [54] & [166] & \\
\hline & peripheral blood (plasma) & [140] & [13] & [149] & [152] & [89] & [54] & {$[112,166]$} & \\
\hline & serum $^{a}$ & [141] & [144] & [149] & {$[152]$} & [97] & {$[52]$} & [167] & [169] \\
\hline & umbilical cord blood & n.r. & n.r. & n.r. & n.r. & n.r. & n.r. & n.r. & n.r. \\
\hline \multirow[t]{2}{*}{ Body fluids } & saliva & [19] & [13] & n.r. & $?$ & {$[88,89,97]$} & {$[52]$} & n.r. & n.r. \\
\hline & urine & [19] & [19] & [75] & [104] & {$[88,89,97]$} & [54] & {$[110,112]$} & [124] \\
\hline
\end{tabular}

VHF Viral haemorrhagic Fever, ${ }^{a}=$ NAT \& Immunological test, n.r. not reported

S2). Interestingly, the twenty-two selected publications described very well the progress of using saliva and urine as non- invasive samples. Based on the existing IgG ELISA for serology, they found that the IgG levels in saliva could be applied to differentiate between dengue primary and secondary infection [1]. One year later, Artimos de Oliveira et al., used saliva for detection of specific IgM of recent infections [12]. In 2000 Torres et al., found for the first time evidence of DENV RNA in saliva and plasma by RT-PCR [13]. The evaluation of saliva samples as alternative approaches for serological diagnosis (IgM, IgG, IgA) was further investigated and complemented by more systematic kinetics analysis of $1^{\text {st }}$ and $2^{\text {nd }}$ infections also comprising urine as an additional alternative sample $[14,15]$. Since the sensitivity (93.3\%), specificity (100\%), positive predictive value (100\%), and negative predictive value $(83.3 \%)$ of the detection of IgG in saliva are high, it was considered as promising sample type for dengue diagnostics [16]. Also in case reports analysing acute infections, the detection of DENV in urine and saliva by RT-PCR as well as the application of filter-paper for saliva sampling prove the usefulness of these non-invasive samples [17-19]. The utility of saliva in an assay that detects DENV-specific IgA in the early phase of a $2^{\text {nd }}$ dengue infection shows $100 \%$ sensitivity from day-one after fever onset with a good correlation to IgA levels in serum and $97 \%$ specificity [20]. DEN NS1 antigen was detected in urine in around two third of dengue fever and DEN haemorrhagic fever (HF) using ELISA. Follow up the excretion of NS1 in urine is very important particularly in patients developing DF or DHF as an indication of protein leakage. The study demonstrates that the NS1 strip assay is less sensitive for urine compared to the ELISA and both assays need further adaptation to improve the sensitivity [21]. This was confirmed by a later study from Saito et al. showing that urine samples could be used for NS1 antigen ELISA but only in case of serum samples are very limited or in poor resource settings [22].

From 2012, more studies were performed using saliva and urine samples besides serum for quantitative RT-PCR and other parameters (NS1, IgM, IgG) for dengue diagnostic during the course of the disease [23-25]. Further studies underline the benefit of saliva as a diagnostic tool for use in developing tropical countries like India nevertheless further research is encouraged before implementation [26]. The delayed release of DENV in urine allows the diagnosis of an acute dengue infection by RT-PCR and sequencing on day 8 and 18, while the respective serum samples collected on the same period were negative for DENV [27].

All these promising results using urine and saliva samples for diagnostics stimulated further investigations on DENV RNA stability in urine and serum as well as establishing novel diagnostic device (stacking flow platform) for single-step detection of a target antibody in salivary fluid $[28,29]$. Both studies investigated different conditions using urine or saliva samples for the diagnostics. One study focused on the storage conditions for these samples while the other improved the sample processing to optimize diagnostics using saliva. Andries et al. performed a representative study by analysing plasma, saliva and urine in 267 patients by applying various molecular and serological analyses. Unfortunately, the performances of these assays were better upon using plasma samples [30]. Analysing commercial rapid diagnostic tests (RDT) for detection of NS1/IgG/IgA in urine and saliva samples suggested that these RDT kits are of higher specificity and limited sensitivity [31]. Interestingly, in dengue secondary infection, the IgA in urine at 4-7 days of disease onset is higher than those with $1^{\text {st }}$ infections indicating severe Dengue [32]. Therefore, DENV IgA in urine is an indicator for the disease severity and must be investigated.

\section{Ebola and other viral hemorrhagic fevers (VHFs)}

Ebola virus and other viral hemorrhagic fevers are mostly detected in blood derived samples such as whole blood, plasma or serum. Recent studies reported Ebola detection also in body fluids including saliva, urine, sweat, tears, semen and vaginal discharge as well as feces, ammonitic fluids, placenta and breast milk (Table 
1 and Additional file 1: Table S3).The search for alternative sampling for Ebola yielded 34 publications from which 11 were performed during the recent Ebola outbreak from 2015/2016. Other publication were found for other VHF viruses like Hanta, 9 hits; Marburg, 4; Junin, 3; VHFs in general 2; Lassa, 2; Crimean Congo hemorrhagic fever (CCHF), 2; Rift Valley fever (RVF), 1; Guanarito, 1 and 1 for a novel Bunya virus.The first report dated from 1980 for RVF virus detection in saliva based on experimentally infected sheep and showed successful virus isolation from saliva [33]. This was completed by the extensive analysis of infected rodents as main transmission vectors for Hantavirus [34]. Besides virus excretion, Hanta virus could be demonstrated in several organs (lung, kidney, salivary glands and liver) by virus isolation from saliva, urine and feces for up to one year post inoculation. Also the intensive investigation of an imported Lassa case to the UK demonstrated the high viral load in blood taken eleven days post onset of the disease as well as significant virus count in urine on day 36, while throat swabs did not yield any detectable virus [35]. These findings were confirmed during the intensive analysis of an acute Lassa virus infected patient when the use of urine as additional sample to serum was successfully investigated for viral RNA by PCR [36].

Vereta and colleagues used urine and urine sediment epithelium for the identification of acute Hanta virus patients showing hemorrhagic fever with renal syndrome (HFRS) [37, 38]. Urine becomes an important sample for serological studies since antibody excretion in the urine coincided with the period of renal structure damage and stopped when the normal renal function was restored. The first successful Hantavirus isolation of a fatal HFRS case used urine and brain tissue and was further confirmed by RT-PCR [39]. Henceforward, urine was used for antigen and genome detection as well as for serology in experimentally infected pigs demonstrating that pigs can be the host for the viral transmission of HFRS virus [40]. Petterson et al. could demonstrate that hantavirus RNA was found in saliva few days after disease onset [41]. The association between the anti-Hantavirus IgA and Hantavirus RNA in saliva was inverse, the same is true for detecting RNA and antigen in endothelial cells within the parotid gland of HFRS patients [42]. In a recent study, the anti-Hantavirus antibodies in saliva was detected in a risk group in farms in Yorkshire, UK [43]. Hereby, the non-invasive saliva sampling confirms the usefulness of Hantavirus surveillance studies for analyzing the presence of Hantavirus in previously unknown risk areas. Also a recent investigation of Hanta virus persistence in wild rodents is based on the analysis of viral RNA in saliva, urine and feces show a peak during the first month after seroconversion continuing throughout the 8 month study [44].
Urine and saliva as non-invasive samples were also successfully used for analyzing the pathogenesis of Junin virus in the rodent vector responsible for virus transmission for up to 480 days post infection [45, 46]. Surviving animals showed a viral dissemination in brain, spleen, kidney and salivary glands with half of the animals shedding Junin virus and the other half being negative for infectious virus, while seroconverted. These findings were successfully used for analyzing the prevalence of Junin virus in the rodent population in endemic areas defining risk areas for the Junin virus infection [47].

Non-invasive samples like urine were used for the analysis of guinea pig and Rhesus macaques infectivity experiments with highly infectious and deadly Marburg virus [48]. In particular for dangerous biosafety level 4 pathogens the sampling of blood is very risky and laboratory infections are possible, which can be avoided by sampling urine. In the guinea pig model, the persistent shedding of Marburg virus in saliva, urine and feces showed that as early as by the end of incubation period and throughout the disease, the virus could be found in the feces and saliva virtually in the same concentrations [49], while in the blood the content of the virus was high and increased by the end of the disease. A similar approach was used investigating bat fecal and urine samples for Marburg virus after infection of a tourist visiting a cave in Uganda [50]. Around $2.5 \%$ of liver/spleen tissues of captured bats were positive in RT-PCR for Marburg virus. Moreover, the virus was detected in 15 different tissues and plasma of Egyptian fruit bats subcutaneously inoculated with Marburg virus, while limited results were obtained applying mucosal swab samples, urine and fecal samples [51].

Antibodies against Ebola virus could not be found in oral fluids, while $100 \%$ agreement between the presence of RNA in serum and oral fluids by RT-PCR was observed [52]. Moreover, in 26 confirmed Ebola cases, 16 samples including saliva, stool, semen, breast milk, tears, nasal blood and a skin swab were positive in Ebola culture and/or RT-PCR [53]. In case of EBOV, all samples including body fluids must be handled applying the WHO recommendations, since they are highly infectious.The recent Ebolavirus outbreak in Serra Leone, Liberia und Guinea with 11,325 deaths initiated several intensive investigations of different patient specimens like blood, urine, sweat, saliva, conjunctival swaps, stool and semen for infectious virus $[54,55]$. These became a major interest since transmission routes were not always obvious from previous experience. Moreover, public health measures require clear references, when recovered patients are not infectious anymore and can be released from quarantine. The excretion of EBOV in body fluids from infected or recovered patients create a great risk for person in contact $[54,56]$ as the Ebola virus 
RNA was detected in the following body fluids weeks up to several months after infection: saliva, conjunctiva/ tears, stool, vaginal fluid, sweat, urine, amniotic fluid, aqueous humor, cerebrospinal fluid, breast milk, and semen raised many concerns regarding the long term transmissibility of infectious virus causing a recrudesce of an outbreak [56-58]. Comparing whole-blood with urine specimen's analysis from Ebola patients in a novel diagnostic film-array with RT-PCR shows a reasonable match of $90 \%$ for whole blood and $85 \%$ for urine [59]. Testing the stability of Ebola virus RNA in human blood and urine under environmental African conditions shows that viral RNA testing from blood samples stored in EDTA buffer is more sensitive [60]. Viral RNA in urine seems less stable compared to blood since urine samples were found positive by RT-PCR by day 10-14 compared to blood until at least day-18. Since the CCHF outbreak in Turkey in 2002, the detection of virus in other body fluids received attention to avoid secondary infections. RNA of CCHF virus was identified in the saliva and the urine of $5 / 6$ and $2 / 3$ patients, respectively [61]. This was confirmed by a later study, which detected CCHF virus in urine samples of patients with prolonged viremia [62].

Furthermore, nasopharyngeal aspirates and/or urine were considered as diagnostic samples evaluating a multiplex hybridization array for detecting various infectious diseases [63]. Interestingly, the Plasmodium falciparum was identified as a cause of death in a case of hemorrhagic fever like illness during the Marburg hemorrhagic fever outbreak in Angola in 2004-2005. Also a novel diagnostic array based on beads technology for detection of multiple bat-borne viruses including Ebola and Nipha viruses used urine from wild bats from Australia and Bangladesh for a surveillance study [64].

Analyzing cases in China of a hemorrhagic fever due to a novel Bunya virus, the RNA was identifed in the blood as well as in urine, throat, and fecal specimens [65]. Further studies are necessary to investigate the significance of non-invasive samples for analyzing the virus pathogenesis and the infectivity of different body fluids.

\section{West Nile}

Clinical specimens used for WNV detection are blood derived samples and CSF (Table 1 and Additional file 1: Table S4). Since the safety of blood banks was important, testing of blood samples was the evident choice. Even though Steele et al. found infectious WN in several organs (brain, heart, spleen, liver, kidney, adrenal intestines, pancreas, lung and ovary) of birds, it took four years until Tesh and others published the investigation of urine samples used for pathogenesis studies in hamsters and birds [66-69]. These findings were later confirmed in different animal models like chipmunks, fox squirrels, hamsters and mice analyzed for WNV pathogenesis research [70-74]. The first report of WN detection in urine was in an acute severe case with encephalitis found positive eight days after symptoms onset [75]. Further studies detected WNV RNA up to 6.7 years in urine indicating for a persistent renal infection for several years [76]. This was confirmed by a number of studies demonstrating the long persistence of WNV particularly in patients with WN fever compared to patients with WN neuro-invasive disease, which had a higher vireamia for a shorter period than those with West Nile fever [77-80]. In the meantime, the advantage of using urine instead or additionally to serum is demonstrated by many investigations and could prove its value also for routine diagnostic [81-86]. Also WNV could be successfully isolated from urine samples and further analyzed by sequencing.

In summary, one could state that the use of urine is a suitable alternative diagnostic sample compared to serum and should be listed in fact sheets from national and international organizations (WHO, PAHO, CDC, ECDC). Further studies are needed investigating if urine samples are a useful source for surveillance studies for WNV distribution and for analyzing the severity of the disease in patients with neuro-invasive and/or kidney manifestation.

\section{Zika}

The Zika virus was detected in blood, serum, saliva, and urine, as well as in semen, vaginal discharge, sweat, tears, ammonitic fluids, placenta and breast milk (Table 1 and Additional file 1: Table S5). The expansion of Zika to Brazil via New Caledonia 2015 stimulates the development of diagnostic assays for NAT and serology to analyze the increasing number of cases [87]. In a surveillance study, ZIKV was identified in $19.2 \%$ (total 182 patients) of saliva samples, but not in blood [88]. The detection of ZIKV in saliva samples increased the molecular detection rate of ZIKV in acute case but ZIKV did not persist for longer time frame in saliva as in urine or semen. Nevertheless, saliva sample was advantageous in children and neonates [89]. Interestingly, the ZIKV can be detected in urine samples for even longer. Combination of urine and saliva besides serum is of great significant in ZIKV diagnostics [90]. This was also true in a rhesus macaque model used for analyzing plasma, saliva, urine and cerebrospinal fluid by RT-PCR for ZIKV detection [91].

Moreover, RNA of ZIKV was detected in semen by RT-PCR on the $7^{\text {th }}$ day of the appearance of symptoms but was not identified on the $21^{\text {st }}$ day, which was confirmed by Reusken et al. [92, 93]. This finding consequently leads to the possibility of an infection via sexual intercourse as documented by D'Ortenzio et al. with a 
high viral load in the semen obtained on sample collected after 18 days $[94,95]$. In several smaller and bigger studies, the usability of saliva and urine beside blood samples was demonstrated for the Zika virus diagnostics [96-98]. The excretion of viral RNA in urine and saliva was observed for up to 29 days after symptom onset and with higher viral load than in blood $[99,100]$. The high risk for transmission by patient's body fluids also raised concern for appropriate safety measures for health care personal as discussed in several publications [101-103].

\section{Yellow Fever}

Yellow Fever is generally detected in blood, plasma, serum and CSF as other flaviviruses (Table 1 and Additional file 1: Table S6). Although alternative samples demonstrate their usefulness for other flavivirus infections like urine or saliva samples for diagnostics of dengue or West Nile, YF were not investigated until 2011 $[104,105]$. These are the first reports showing the usefulness of urine samples for diagnostic of adverse events after YF vaccination. For vaccinees developing severe side effects after vaccination it could be clearly shown that viral shedding is prolonged up to day 25 post vaccination. The release of YF RNA could be found in urine at day 198 after vaccination. If the detection of the YF attenuated 17D vaccine virus could be demonstrated in urine easily. However, representative data of alternative samples like urine or saliva from YF infections are missing. In particular for cases with a severe course of disease with numerous hemorrhagic bleedings the use of non-invasive sampling would be a real alternative preventing bodily injury of the patient.

\section{Severe acute respiratory syndrome (SARS)}

When SARS emerged in November 2002, it was obvious to analyze samples from the respiratory tract for diagnostic. However, even for the first SARS patients other samples beside blood and nasopharyngeal aspirate samples like feces and urine were found positive with $97 \%$ and $42 \%$ for viral RNA, respectively [106] (Table 1 and Additional file 1: Table S7). This was confirmed by analysis of throat wash and saliva showing a high virus load up to $6 \times 10^{6}$ and $6 \times 10^{8}$ RNA copies per ml, respectively [107]. Moreover, the detection of SARS in plasma, sputum, endotracheal aspirates, stool, throat swabs and saliva revealed significant differences between the types of samples [108] as all samples from the lower respiratory tract were tested positive. Cheng et al. found that death was associated with higher virus load in nasopharyngeal specimens obtained on day 10 after the onset of symptoms [109]. Different samples like serum, nasopharyngeal aspirates (NPA), throat swabs, nasal swabs, rectal swab, stool and urine were used for analysis of the viral pathogenesis during the course of the disease [109-112].
The diarrhea and hepatic dysfunction was associated high viral load in NPA, while in urine is associated with abnormal urinalysis findings. The extensive analysis of 415 SARS patients revealed the presence of SARS in respiratory specimens two weeks after disease onset, and in stool, rectal swab and urine specimens for up to four weeks. Throat and nasal swabs is less significant that the NPA specimens, therefore, the high viral load in NPA has a major impact on the airborne transmission, which played a major role during the outbreak in Hong Kong [113].

The evaluations of commercial PCR kits and in-house antigen-ELISAs for the quality of SARS diagnostic are an important task to select the most appropriate test for the selected sample. The sensitivity of RT-PCR is higher compared to two antigen-ELISAs [114] as RNA of SARS-CoV can be detected earlier in fecal specimens in around $80 \%$ of patients and in $25 \%$ of urine samples. Based on all these findings, RT-PCR is the method of choice for early diagnosis of SARS CoV infection $[115,116]$.

The co-presence of viral RNA and antibodies in plasma was observed over three weeks in two cases [117]. In addition, the SARS-CoV was isolated from stool or urine specimens for longer than 4 weeks [118]. Since the detection of SARS virus is possible in various clinical samples (NPA, throat-swab, fecal, cerebrospinal fluid, blood and urine) by viral culture or RT-PCR clear and significant recommendations for diagnostic of SARS based on the previous experiments worked out by the WHO and the Multi-Centre Collaborative Network require an appropriate update. Even though SARS did not appear any more after the outbreak except for the two laboratory infections thereafter [119-171].

Bats are the most likely animal vector for CoVs [121]. Also experiments in mice and rhesus macaque analyzing the viral pathogenesis for the development of effective strategies for diagnosis, prevention, therapy and vaccine design was further evaluated [122, 123]. Since salivary gland epithelial cells were affected as a first target after infection the immunization with virus like particles might be eliciting a protective immune response against SARS-CoV generating a mucosal immunity. This new vaccine approach provides important information for future vaccine design.

\section{Middle East respiratory syndrome coronavirus (MERS- CoV)}

A boost of nearly 50 publications on alternative sampling within three years demonstrates the importance and documents the public health concern with this respiratory disease caused by a new Corona virus ( $\mathrm{CoV}$ ) (Additional file 1: Table S8). The publications can be roughly categorized as follows 11 case reports, 7 descriptions of pathogenesis, 
11 on recommendation and investigation of diagnostics, 7 on recommendation and analysis of risks for health care workers, 2 recommendations for patient management and 5 on control and prevention including treatment and vaccine development. Only a few selected publications were considered for this review. Bronchoalveolar and lower respiratory tract fluids were highly positive for MERS-CoV in the two identified cases [124], while urine samples were only positive on day 13. Stool samples and oro-nasal swabs contained very low MERS-CoV copy number on days 12 and 16, respectively, and no virus was detected in blood. In the beginning of the outbreak the way of transmission was rather unclear. Therefore, the virus replication in the kidney with potential shedding in urine was further investigated [125]. To clarify the different transmission routes a prediction model for oral-fecal and/or oral-saliva transmission routes for MERS-CoV was developed and evaluated [126]. Very soon camels as contributing animal host for MERS-CoV infection got into focus of investigation and it became obvious that also dromedary camels in Eastern Africa and the Arabian Peninsula have a very high seroprevalence of MERS-CoV antibodies [127]. For further surveillance studies in camels, hedgehogs, and bats very often non-invasive samples like urine, saliva, fecal nasal swaps, fecal swaps or camel milk were used to analyze for MERS-CoV RNA or specific antibodies [128]. In summer 2015, 183 confirmed cases of MERS and $33 \mathrm{fa}-$ talities were reported in the Republic of Korea caused by a nosocomial outbreak [129].

The timing and intensity of respiratory viral shedding in MERS-CoV infected patients is still of major interest as airborne transmission from human to human by droplets seems to be the dominant infection route [130132]. It might be that the introduction of the isothermal amplification (LAMP or RPA) for detecting of emerging diseases provides a useful tool for quick and reliable diagnostic of acute cases and might lead to an immediate public health response including the appropriate safety precautions for the medical personal $[133,134]$.

Based on the experience with other respiratory infections and based on the lessons learned from the previous SARS outbreak the analysis of respiratory samples are parts of the routine samples taken for diagnostic of suspected MERS patients.

\section{Conclusions}

The analysis of using other non-invasive samples for virus diagnostics clearly shows that the procedures for the optimal sampling strategy of the different viral infections are not seriously investigated table S9. In the following overview it became obvious that for the newly emerging viruses like $\mathrm{CHIK}$, MersCoV and Zika more and broader attempts for sampling strategies were performed and investigated than for well known viruses like YF and dengue.

The application of saliva as a sample of choice for the diagnosis of CHIK fever infections in small children or patients whose blood samples are difficult to obtain is of great significant. However, all recommendations/fact sheets for CHIK from national and international organizations (CDC, PAHO, WHO, ECDC) do not mention saliva or urine samples as suitable material for diagnosis because of the missing of meaningful studies that evaluate saliva and urine as diagnostic samples compared with blood. Hopefully, there will be studies performed answering these questions with a representative number of CHIK patients in the future.

The use of saliva and urine for the diagnosis of acute dengue infections is of great importance and requires more attention. Present studies show the usefulness for these samples for diagnostics and also the monitoring of the severity of infection. In particular for surveillance studies and/or investigation of small children the noninvasive approach using saliva or urine for the laboratory diagnosis of dengue cases should be considered when blood samples are difficult to obtain. Although the application of alternative samples for the diagnostic became more popular in the recent years, further studies and improvements are necessary to establish these samples equally to common plasma or serum samples. Commercial assays as well as appropriate sampling equipment have to be verified for diagnostic applicability in representative cohorts and during the course of the disease. It seems that the increased awareness of alternative samples stimulates such studies for dengue diagnosis as demonstrated in the recent publications mentioned above.

In particular for diagnostic of VHF cases, the investigation of the usefulness of non-invasive taken samples should have high priority since blood sampling from such patients is highly risky and often dangerous for patients with hemorrhagic symptoms while continuous bleeding occurs. The virus load in sever cases of VHF is very high in body fluid and the NAT is the method of choice since the production of specific IgM and/or IgG antibodies takes a few days. In very severe cases, the patient even can pass away before developing a detectable antibody reaction, while a general viremia affecting several organs and is detectable in most body fluids. In less severe cases, the exact moment becomes an important issue since viremia only remains for just a few days (3-4 days) and often patient samples were taken too late for successful NAT thus requiring laborious serology testing with in-house assays and risk of false positive reactivity. Onset of disease is also not a well-defined point of time because the perception of a disease might be different in developing compared to developed countries. This makes the comparison of clinical 
symptoms and diagnostic findings during the course of the disease even more difficult.

Although the analysis of different body fluids during the recent Ebola virus outbreak expands our knowledge of virus transmissibility via eye fluid and semen tremendously, systematic studies on which and for how long the different body fluids will contain viral RNA and/or infectious viruses are still missing. Recommendations on how non-invasive sampling should be performed, what kind of samples are necessary and how they should be stabilized and transported under African environmental conditions are still missing and require thoroughly investigations.

For WNV infections the use of urine is a suitable alternative diagnostic sample compared to serum and should be listed in fact sheets from national and international organizations. Further studies are needed investigating if urine samples are a useful source for surveillance studies on WNV distribution and for analyzing the severity of the disease in patients with neuro-invasive and/or kidney manifestation. The emergence of Zika virus tremendously stimulated the investigation of using non-invasive samples as saliva and urine for diagnostic of Zika virus infections. From the start of the Zika outbreak in French Polynesia saliva was considered as alternative material for the diagnostics. The investigation of urine and saliva shows a higher virus load compared to blood making these samples a suitable alternative to blood. However, this information has to be forwarded to the physicians as it is already part of the $\mathrm{PAHO}$ and $\mathrm{WHO}$ recommendations.

For YF diagnostic one can hope that the integration of saliva and urine as alternative samples into the recommendation worked out by the WHO for the recent outbreak will help to implement this method into the medical procedure and create some meaningful results for future outbreak scenarios.

Even although SARS seems to have disappeared from the globe, the experience and findings on which and when the different diagnostic samples should be used for a quick and reliable diagnostic should be carefully evaluated, since respiratory infections are on the rise as we have seen a few years later by the influenza and MERS-CoV outbreaks. The great variety on which, how and when respiratory samples have to be taken is reflected by the list of nomenclature found in the publications: for upper respiratory specimens (nasal swab, exudate nose, oronasal swab, pharyngeal swab, tracheal swab, exudate mouth, saliva and sputum) and lower respiratory specimens (bronchoalveolar fluid, bronchoalveolar lavage). Recommendations for standardized procedures for sampling and handling of the respiratory samples will help to allow a better comparison of the findings and provide a better preparedness for the next respiratory disease outbreak.
Because of a higher virus load, samples from the lower respiratory tract are more suitable for diagnostic. However, the sampling of bronchoalveolar-lavage fluid is also invasive and requires an experienced physician and holds a certain risk of nosocomial infections by aerosols. Other non-invasive samples like urine, nasal, pharyngeal, tracheal and rectal swabs were included in the diagnostic analysis for analyzing the pathogenesis and the kinetic of virus release by the different body fluids. Like for SARS standardized procedures for sampling and handling of the respiratory samples will help to allow a better comparison of the findings and provide a better preparedness for future respiratory disease outbreak.

The present review clearly shows that there is still the need to perform more diligent studies analyzing non-invasive patient samples in comparison with blood and serum samples, which used for routine diagnostic of emerging viral diseases. While for some diseases like the respiratory infections, the sampling of nasal swaps and saliva is part of routine sampling, for other viral infections, blood or serum seems the predominant and only type of sample used for laboratory diagnosis.

This is in particular disappointing because non-invasive sampling offers a real alternative avoiding additional risk for the patient and the medical personal. Patients suspected to be infected by VHF usually have a very high virus load. Therefore, the analysis of saliva or urine should be routinely performed in parallel to investigation of blood samples. Based on a solid database it will be possible to determine the most appropriate sample for a viral diagnosis before it gets implemented in the routine diagnostic procedure. Diagnostic laboratories and physicians have to gain knowledge when and how alternative samples have to be considered for analyzing an acute or convalescent viral infection. Even though, we have with NAT a very sensitive diagnostic tool, the best point in time during the course of the disease together with the optimal sampling, sample storage and sample preparation are essential to get optimal results for a laboratory diagnosis. In patients presenting with a moderate or mild disease, the viremia is mostly very short lasting just 1-3 days. For these patients the positive NAT is sometimes difficult to achieve and a negative finding is of no predictive value since the virus titer might be just below the detection limit or sample storage and sample preparation is not optimal in case of non-invasive sampling such as saliva and urine. Although the virus disappeared from the blood, the virus genome will be still detectable in the urine as consequence of the clearance process as we have found in Yellow Fever vaccinees or other for Zika [97, 104]. In contrast, we find a high viral load in patients developing a severe disease sometimes with a general infection affecting several organs. In particular in those patients, the detection of the 
pathogenic virus by NAT is not difficult analyzing different types of samples. Very often the viral load also reflects the severity of the disease and can be used as prognostic marker for progression of the disease in the patient. Exactly for these patients the non-invasive sampling is less stressful as frequent bleeding performed with the current procedure. This becomes even more important, if point of care diagnostic allows a more frequent monitoring of infection parameters of the diseased patient in the future. For the recently emerging CHIK and Zika in South America, the analysis of throat swaps, saliva and urine samples were already analyzed for their usability in diagnostics. However, the findings are based on case studies or small studies and require a more systematic approach. Preferably there should be performed a systematic analysis of different invasive samples (blood, bronchoalveolar lavage) and non-invasive samples (saliva, urine, etc.) for their diagnostic value using different diagnostic methods for patients with acute and convalescent disease when new infections emerge. This also implies that the procedure taking samples has to be somehow standardized. This became very obvious by the large number of terms for upper and lower respiratory samples most likely reflecting the great variety how the samples were taken. This makes the comparability of diagnostic findings presented in different studies very difficult. To address this problem a clear recommendation for the sampling procedure would help to overcome this imponderability. Furthermore, the methods for storage of the samples regarding temperature and stabilization needs to be worked out to allow an optimal transport and preparation of the diagnostic sample. For example there are special sampling tubes with stabilizer available for both saliva (DNAgard Saliva by biomatrica, USA) and urine (VACUETTE Urine CCM tubes by Greiner Bio-One, Germany and Urine Monovette by Sarstedt, Germany), which will help preserves the integrity of sample at room temperature. Sample preparation from urine and saliva could be also challenging especially for molecular diagnostics, therefore it is very important to optimize protocols using clinical samples rather than spiked mock-samples. Our personal experience showed that the optimized sample preparation method on real clinical samples was not as efficient as on spiked mock samples.

The increasing number of publications considering alternative sampling for diagnostic of the recent outbreaks MERS-CoV, CHIK, Ebola and Zika are promising. However, systematic studies are rare and for some infectious disease outbreaks like the recent yellow fever in Angola, non-invasive samples for diagnostic are still uncommon and require further investigation. Just for diseases like yellow fever, non-invasive samples like urine or saliva might be a very practical alternative, since the first index patients are detected often very late, while blood will be negative by NAT in patients with mild disease and from patients with a severe disease it is difficult taking blood because of a hemorrhage clinical picture. Non-invasive samples might be also a great alternative for investigations of children or other patients were collection of blood samples is difficult [18, 30, 88]. Also for large surveillance studies, non-invasive samples like saliva and/or urine could be performed without medical personal for collecting blood. However, the usability of these samples for serology or NAT has to be evaluated in comparison to conventional use of sera. Therefore, it is necessary to introduce non-invasive sampling strategies in recommendations as done for the "Yellow Fever Laboratory Diagnostic Algorithm" worked out for the epidemic and non-epidemic countries in Africa during the YF outbreak in Angola by WHO expert team [135]. Since these investigations could be only performed during an outbreak situation the preparation of a scheme for evaluation of sampling for respiratory as well as for other infectious diseases including the further processing for laboratory diagnostic is highly recommended. This more structured approach will help to improve the diagnostic of emerging infectious diseases significantly as new diagnostic methods and platforms are developed continuously and require effective evaluation under real conditions.

For confirmation of a clinical diagnosis a correct laboratory diagnosis is essential for all further steps of patient's treatment and handling. In particular for new and/or emerging diseases, the conditions for the best sampling regarding time and source (blood, serum, saliva, urine, etc.) are often not known. Since every disease has its own course of symptoms and affected organs, the optimal sampling schema might change and require different strategies regarding sample preparation and processing. While in the early phase when disease symptoms appear often the viral pathogen could be detected by nucleic acid testing in blood or other body fluids in the later phase only antibodies are detectable in serum.

In the present article, we analyzed over 700 scientific publications on diagnostic approaches for dengue, West Nile, SARS, chikungunya, MERS-CoV, Ebola, Zika and Yellow Fever regarding their relevance for using alternative samples like saliva and urine for their versatility for virus diagnostic. The use of non-invasive samples offers a suitable alternative for improving the diagnostic performance and significantly reduces the risk for medical personal and patients for routine diagnostic and during an outbreak situation. The advantage of using non-invasive samples for the diagnostic has to be seriously analyzed and investigated before implementing in the routine diagnostics. 


\section{Additional file}

Additional file 1: Figure S1. Selection scheme flowchart. Abbreviation: $\mathrm{CHIV}=$ Chikungunya Virus, VHF = Viral Hemorrhagic Fever, $\mathrm{WN}=$ West Nile, YF $=$ Yellow fever. Table S1. Analysis of different sampling methods for diagnostic of CHIK virus infection. Table S2. Analysis of different sampling methods for diagnostic of Dengue virus infection. Table S3. Analysis of different sampling methods for diagnostic of Ebola/VHF virus infections. Table S4. Analysis of different sampling methods for diagnostic of West Nile virus infection. Table S5. Analysis of different sampling methods for diagnostic of Zika virus infection. Table S6. Analysis of different sampling methods for diagnostic of Yellow Fever virus infection. Table S7. Analysis of different sampling methods for diagnostic of severe acute respiratory syndrome (SARS) virus infection. Table S8. Analysis of different sampling methods for diagnostic of Middle East respiratory syndrome coronavirus (MERS-CoV) infection. (DOCX $162 \mathrm{~kb}$ )

\section{Abbreviations}

AG test: Antigen capture test; CCHF: Crimean Congo hemorrhagic fever; CDC: Centers for Disease Control and Prevention; CHIK: Chikungunya; CoV: Corona virus; CSF: Cerebrospinal fluid; DENV: Dengue virus; DF: Denge fever; DHF: Dengue hemorrhagic fever; EBOV: Ebola virus; ECDC: European Centre for Disease Prevention and Control; ELISA: Enzyme-linked immunosorbent assay; GAPDH: Glyceraldehyde 3-phosphate dehydrogenase; HAl: Hemagglutination inhibition assay; HF: Hemorrhagic fever; HFRS: Hemorrhagic fever with renal syndrome; IFA: Immunofluorescence assay; IgA: Immunoglobulin A; IgG: Immunoglobulin G; IgM: Immunoglobulin $\mathrm{M}$; IH: Immune histochemistry; LAMP: Loop-mediated isothermal amplification; LRS: Lower respiratory specimens; MERS-CoV: Middle East respiratory syndrome coronavirus; NAT: Nucleic Acid Test; NPA: Nasopharyngeal aspirates; NS1: Nonstructural protein 1; PAHO: Panamerican Health Organisation; PCR: Polymerase Chain Reaction; PRNT: Plaque reduction and neutralization test; RDT: Rapid diagnostic test; RNA: Ribonucleic acid; RPA: Recombinase polymerase amplification; RTPCR: Reverse transcriptase polymerase chain reaction; RVF: Rift Valley fever; SARS: Severe acute respiratory syndrome; TMA: Transcription-mediated

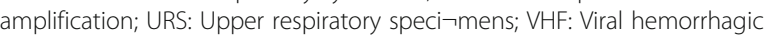
fever; VI: Virus isolation; WHO: World Health Organisation; WN: West Nile: WNV: West Nile virus; YF: Yellow fever; ZIKV: Zika virus

\section{Acknowledgements}

The authors thank Véronique Millot from the World Health Organization for help with the literature search.

\section{Funding}

No specific funding was obtained for preparing the manuscript.

\section{Availability of data and materials}

All publications evaluated for the analysis are provided in the supplement part of the manuscript.

\section{Authors' contributions}

MN, PP, AA, SY made substantial contributions to conception and design, or acquisition of data, and analysis and interpretation of data. MN, PP, AA, RS are involved in drafting the manuscript or revising it critically for important intellectual content. All authors (MN, PP, AA, RS, SY) have participated sufficiently in the work and given final approval of the version to be published. All agreed to be accountable for all aspects of the work in ensuring that questions related to the accuracy or integrity of any part of the work are appropriately investigated and resolved.

\section{Ethics approval and consent to participate}

Since the publication is based on previously published data and does not comprise own investigations an ethical approval is not applicable.

\section{Consent for publication}

"Not applicable" see comment above

\section{Competing interests}

The authors declare that they have no competing interests.

\section{Publisher's Note}

Springer Nature remains neutral with regard to jurisdictional claims in published maps and institutional affiliations.

\section{Author details}

${ }^{1}$ Robert Koch Institute, Berlin, Germany. ${ }^{2}$ TIB MOLBIOL Syntheselabor GmbH, Berlin, Germany. ${ }^{3}$ Division of Microbiology and Animal Hygiene, University of Goettingen, Goettingen, Germany. ${ }^{4}$ Control of Epidemic Diseases (CED), World Health Organization, Geneva, Switzerland.

Received: 9 October 2017 Accepted: 10 December 2018 Published online: 29 December 2018

\section{References}

1. Cuzzubbo AJ, Vaughn DW, Nisalak A, Suntayakorn S, Aaskov J, Devine PL. Detection of specific antibodies in saliva during dengue infection. J Clin Microbiol. 1998;36(12):3737-9.

2. Koraka P, Zeller H, Niedrig M, Osterhaus AD, Groen J. Reactivity of serum samples from patients with a flavivirus infection measured by immunofluorescence assay and ELISA. Microbes Infect. 2002:4(12):1209-15.

3. Vazeille M, Moutailler S, Coudrier D, Rousseaux C, Khun H, Huerre M, Thiria J, Dehecq JS, Fontenille D, Schuffenecker I, et al. Two Chikungunya isolates from the outbreak of La Reunion (Indian Ocean) exhibit different patterns of infection in the mosquito, Aedes albopictus. PLoS One. 2007;2(11):e1168.

4. Powers $\mathrm{AM}$, Logue $\mathrm{CH}$. Changing patterns of chikungunya virus: reemergence of a zoonotic arbovirus. J Gen Virol. 2007;88(Pt 9):2363-77.

5. Rezza G, Nicoletti L, Angelini R, Romi R, Finarelli AC, Panning M, Cordioli $P$, Fortuna C, Boros S, Magurano F, et al. Infection with chikungunya virus in Italy: an outbreak in a temperate region. Lancet. 2007:370(9602):1840-6.

6. Simon F, Parola P, Grandadam M, Fourcade S, Oliver M, Brouqui P, Hance P, Kraemer P, Ali Mohamed A, de Lamballerie X, et al. Chikungunya infection: an emerging rheumatism among travelers returned from Indian Ocean islands. Report of 47 cases. Medicine (Baltimore). 2007:86(3):123-37.

7. Vanlandingham DL, Hong C, Klingler K, Tsetsarkin K, McElroy KL, Powers AM, Lehane MJ, Higgs S. Differential infectivities of o'nyong-nyong and chikungunya virus isolates in Anopheles gambiae and Aedes aegypti mosquitoes. Am J Trop Med Hyg. 2005;72(5):616-21.

8. Gardner J, Rudd PA, Prow NA, Belarbi E, Roques P, Larcher T, Gresh L, Balmaseda A, Harris E, Schroder WA, et al. Infectious Chikungunya Virus in the Saliva of Mice, Monkeys and Humans. PLoS One. 2015;10(10):e0139481.

9. Musso D, Teissier A, Rouault E, Teururai S, de Pina JJ, Nhan TX. Detection of chikungunya virus in saliva and urine. Virol J. 2016:13:102.

10. Kondo M, Akachi S, Ando K, Nomura T, Yamanaka K, Mizutani H. Two Japanese siblings affected with Chikungunya fever with different clinical courses: Imported infections from the Cook Islands. J Dermatol. 2016;43(6): 697-700.

11. Raut CG, Hanumaiah H, Raut WC. Utilization and Assessment of Throat Swab and Urine Specimens for Diagnosis of Chikungunya Virus Infection. Methods Mol Biol. 2016:1426:75-83.

12. Artimos de Oliveira $S$, Rodrigues CV, Camacho LA, Miagostovich MP, Araújo ES, Nogueira RM. Diagnosis of dengue infection by detecting specific immunoglobulin M antibodies in saliva samples. J Virol Methods. 1999;77(1): 81-6.

13. Torres JR, Liprandi F, Goncalvez AP. Acute parotitis due to dengue virus. Clin Infect Dis. 2000;31(5):E28-9.

14. Balmaseda A, Guzman MG, Hammond S, Robleto G, Flores C, Tellez Y, Videa E, Saborio S, Perez L, Sandoval E, et al. Diagnosis of dengue virus infection by detection of specific immunoglobulin $\mathrm{M}(\mathrm{lg} M)$ and $\lg \mathrm{A}$ antibodies in serum and saliva. Clin Diagn Lab Immunol. 2003;10(2):317-22.

15. Vazquez S, Cabezas S, Perez AB, Pupo M, Ruiz D, Calzada N, Bernardo L, Castro O, Gonzalez D, Serrano T, et al. Kinetics of antibodies in sera, saliva, and urine samples from adult patients with primary or secondary dengue 3 virus infections. Int J Infect Dis. 2007;11(3):256-62.

16. Chakravarti A, Matlani M, Jain M. Immunodiagnosis of dengue virus infection using saliva. Curr Microbiol. 2007;55(6):461-4.

17. Balmaseda A Saborio S, Tellez Y, Mercado JC, Perez L, Hammond SN, Rocha C, Kuan G, Harris E. Evaluation of immunological markers in serum, filter- 
paper blood spots, and saliva for dengue diagnosis and epidemiological studies. J Clin Virol. 2008;43(3):287-91.

18. Mizuno Y, Kotaki A, Harada F, Tajima S, Kurane I, Takasaki T. Confirmation of dengue virus infection by detection of dengue virus type 1 genome in urine and saliva but not in plasma. Trans R Soc Trop Med Hyg. 2007;101(7): 738-9.

19. Poloni TR, Oliveira AS, Alfonso HL, Galvao LR, Amarilla AA, Poloni DF, Figueiredo LT, Aquino VH. Detection of dengue virus in saliva and urine by real time RT-PCR. Virol J. 2010;7:22.

20. Yap G, Sil BK, Ng LC. Use of saliva for early dengue diagnosis. PLoS Negl Trop Dis. 2011;5(5):e1046.

21. Chuansumrit A, Chaiyaratana W, Tangnararatchakit K, Yoksan S, Flamand M, Sakuntabhai A. Dengue nonstructural protein 1 antigen in the urine as a rapid and convenient diagnostic test during the febrile stage in patients with dengue infection. Diagn Microbiol Infect Dis. 2011;71(4):467-9.

22. Saito Y, Moi ML, Kotaki A, Ikeda M, Tajima S, Shiba H, Hosono K, Saijo M, Kurane I, Takasaki T. Detecting Dengue Virus Nonstructural Protein 1 (NS1) in Urine Samples Using ELISA for the Diagnosis of Dengue Virus Infection. Jpn J Infect Dis. 2015;68(6):455-60.

23. Anders KL, Nguyet NM, Quyen NT, Ngoc TV, Tram TV, Gan TT, Tung NT, Dung NT, Chau NV, Wills B, et al. An evaluation of dried blood spots and oral swabs as alternative specimens for the diagnosis of dengue and screening for past dengue virus exposure. Am J Trop Med Hyg. 2012;87(1) $165-70$

24. Hirayama T, Mizuno Y, Takeshita N, Kotaki A, Tajima S, Omatsu T, Sano K, Kurane I, Takasaki T. Detection of dengue virus genome in urine by realtime reverse transcriptase PCR: a laboratory diagnostic method useful after disappearance of the genome in serum. J Clin Microbiol. 2012;50(6):204752.

25. Korhonen EM, Huhtamo E, Virtala AM, Kantele A, Vapalahti O. Approach to non-invasive sampling in dengue diagnostics: exploring virus and NS1 antigen detection in saliva and urine of travelers with dengue. J Clin Virol. 2014;61(3):353-8.

26. Ravi Banavar S, Vidya GS. Diagnostic efficacy of saliva for dengue - a reality in near future? A piloting initiative. J Clin Diagn Res. 2014;8(3):229-32.

27. Ma X, Zhen W, Yang P, Sun X, Nie W, Zhang L, Xu H, Hu K. First confirmation of imported dengue virus serotype 2 complete genome in urine from a Chinese traveler returning from India. Virol J. 2014;11:56.

28. Van den Bossche D, Cnops L, Van Esbroeck M. Recovery of dengue virus from urine samples by real-time RT-PCR. Eur J Clin Microbiol Infect Dis. 2015;34(7):1361-7.

29. Zhang Y, Bai J, Ying JY. A stacking flow immunoassay for the detection of dengue-specific immunoglobulins in salivary fluid. Lab Chip. 2015;15(6): 1465-71.

30. Andries AC, Duong V, Ly S, Cappelle J, Kim KS, Lorn Try P, Ros S, Ong S, Huy $R$, Horwood P, et al. Value of Routine Dengue Diagnostic Tests in Urine and Saliva Specimens. PLoS Negl Trop Dis. 2015;9(9):e0004100.

31. Andries AC, Duong V, Ong S, Ros S, Sakuntabhai A, Horwood P, Dussart $P$, Buchy P. Evaluation of the performances of six commercial kits designed for dengue NS1 and anti-dengue $\operatorname{lgM}, \lg G$ and $\lg A$ detection in urine and saliva clinical specimens. BMC Infect Dis. 2016;16:201.

32. Zhao H, Qiu S, Hong WX, Song KY, Wang J, Yang HQ, Deng YQ, Zhu SY, Zhang FC, Qin CF. Dengue Specific Immunoglobulin A Antibody is Present in Urine and Associated with Disease Severity. Sci Rep. 2016;6:27298.

33. Harrington DG, Lupton HW, Crabbs CL, Peters CJ, Reynolds JA, Slone TW Jr. Evaluation of a formalin-inactivated Rift Valley fever vaccine in sheep. Am J Vet Res. 1980;41(10):1559-64.

34. Lee HW, Lee PW, Baek LJ, Song CK, Seong IW. Intraspecific transmission of Hantaan virus, etiologic agent of Korean hemorrhagic fever, in the rodent Apodemus agrarius. Am J Trop Med Hyg. 1981;30(5):1106-12.

35. Emond RT, Bannister B, Lloyd G, Southee TJ, Bowen ET. A case of Lassa fever: clinical and virological findings. Br Med J (Clin Res Ed). 1982;285(6347):1001-2.

36. Lunkenheimer $K$, Hufert FT, Schmitz $H$. Detection of Lassa virus RNA in specimens from patients with Lassa fever by using the polymerase chain reaction. J Clin Microbiol. 1990;28(12):2689-92.

37. Vereta LA. Elisova TD: [The use of the indirect fluorescent antibody technic for determining viral antigens in the urine of patients with hemorrhagic fever with renal syndrome]. Lab Delo. 1990;5:72-4.

38. Vereta LA, Elisova TD, Voronkova GM. The detection of antibodies to the hantaan virus in the urine of patients with hemorrhagic fever with renal syndrome. Vopr Virusol. 1993;38(1):18-21.
39. Avsic-Zupanc T, Poljak M, Furlan P, Kaps R, Xiao SY, Leduc JW. Isolation of a strain of a Hantaan virus from a fatal case of hemorrhagic fever with renal syndrome in Slovenia. Am J Trop Med Hyg. 1994;51(4):393-400.

40. Yang ZQ, Yu SY, Nie J, Chen Q, Li ZF, Liu YX, Zhang JL, Xu JJ, Yu XM, Bu XP, et al. Prevalence of hemorrhagic fever with renal syndrome virus in domestic pigs: an epidemiological investigation in Shandong province. Di Yi Jun Yi Da Xue Xue Bao. 2004;24(11):1283-6.

41. Pettersson L, Klingstrom J, Hardestam J, Lundkvist A, Ahlm C, Evander M. Hantavirus RNA in saliva from patients with hemorrhagic fever with renal syndrome. Emerg Infect Dis. 2008;14(3):406-11.

42. Pettersson L, Rasmuson J, Andersson C, Ahlm C, Evander M. Hantavirusspecific IgA in saliva and viral antigen in the parotid gland in patients with hemorrhagic fever with renal syndrome. J Med Virol. 2011;83(5):864-70.

43. Jameson LJ, Newton A, Coole L, Newman EN, Carroll MW, Beeching NJ, Hewson R, Christley RM. Reply to comment--Clement et al.: (Prevalence of antibodies against hantaviruses in serum and saliva of adults living or working on farms in Yorkshire, United Kingdom). Viruses. 2014;6(9):3425-7.

44. Voutilainen L, Sironen T, Tonteri E, Back AT, Razzauti M, Karlsson M, Wahlstrom M, Niemimaa J, Henttonen $\mathrm{H}$, Lundkvist A. Life-long shedding of Puumala hantavirus in wild bank voles (Myodes glareolus). J Gen Virol. 2015; 96(Pt 6):1238-47.

45. Vitullo AD, Hodara VL, Merani MS. Effect of persistent infection with Junin virus on growth and reproduction of its natural reservoir, Calomys musculinus. Am J Trop Med Hyg. 1987;37(3):663-9.

46. Vitullo AD, Merani MS. Vertical transmission of Junin virus in experimentally infected adult Calomys musculinus. Intervirology. 1990;31(6):339-44.

47. Mills JN, Ellis BA, Childs JE, McKee KT Jr, Maiztegui Jl, Peters CJ, Ksiazek TG, Jahrling PB. Prevalence of infection with Junin virus in rodent populations in the epidemic area of Argentine hemorrhagic fever. Am J Trop Med Hyg. 1994;51(5):554-62.

48. Pokhodiaev VA, Gonchar NI, Pshenichnov VA. An experimental study of the contact transmission of the Marburg virus. Vopr Virusol. 1991;36(6):506-8.

49. Chupurnova TS, Pisanko VA, Bakulina LF, Zhukov VA, Chepurnov AA. Assay for level of Marburg virus in blood and isolates from experimentally infected animals. Vopr Virusol. 2000;45(2):18-20.

50. Amman BR, Carroll SA, Reed ZD, Sealy TK, Balinandi S, Swanepoel R, Kemp A, Erickson BR, Comer JA, Campbell S, et al. Seasonal pulses of Marburg virus circulation in juvenile Rousettus aegyptiacus bats coincide with periods of increased risk of human infection. PLoS Pathog. 2012;8(10): e1002877.

51. Paweska JT, Jansen van Vuren $P$, Fenton KA, Graves K, Grobbelaar AA, Moolla N, Leman P, Weyer J, Storm N, McCulloch SD, et al. Lack of Marburg Virus Transmission From Experimentally Infected to Susceptible In-Contact Egyptian Fruit Bats. J Infect Dis. 2015;212(Suppl 2):S109-18.

52. Formenty $P$, Leroy EM, Epelboin A, Libama F, Lenzi M, Sudeck H, Yaba P, Allarangar Y, Boumandouki P, Nkounkou VB, et al. Detection of Ebola virus in oral fluid specimens during outbreaks of Ebola virus hemorrhagic fever in the Republic of Congo. Clin Infect Dis. 2006;42(11):1521-6.

53. Bausch DG, Towner JS, Dowell SF, Kaducu F, Lukwiya M, Sanchez A, Nichol ST, Ksiazek TG, Rollin PE. Assessment of the risk of Ebola virus transmission from bodily fluids and fomites. J Infect Dis. 2007;196(Suppl 2):S142-7.

54. Kreuels B, Wichmann D, Emmerich P, Schmidt-Chanasit J, de Heer G, Kluge S, Sow A, Renne T, Gunther S, Lohse AW, et al. A case of severe Ebola virus infection complicated by gram-negative septicemia. N Engl J Med. 2014; 371(25):2394-401.

55. Petrosillo N, Nicastri E, Lanini S, Capobianchi MR, Di Caro A, Antonini M, Puro V, Lauria FN, Shindo N, Magrini N, et al. Ebola virus disease complicated with viral interstitial pneumonia: a case report. BMC Infect Dis. 2015:15:432.

56. Vetter P, Fischer WA 2nd, Schibler M, Jacobs M, Bausch DG, Kaiser L. Ebola Virus Shedding and Transmission: Review of Current Evidence. J Infect Dis. 2016;214(suppl 3):S177-84.

57. Chughtai AA, Barnes M, Macintyre CR. Persistence of Ebola virus in various body fluids during convalescence: evidence and implications for disease transmission and control. Epidemiol Infect. 2016;144(8):1652-60.

58. Green E, Hunt L, Ross JC, Nissen NM, Curran T, Badhan A, Sutherland KA, Richards J, Lee JS, Allen SH, et al. Viraemia and Ebola virus secretion in survivors of Ebola virus disease in Sierra Leone: a cross-sectional cohort study. Lancet Infect Dis. 2016;16(9):1052-6.

59. Southern TR, Racsa LD, Albarino CG, Fey PD, Hinrichs SH, Murphy CN, Herrera VL, Sambol AR, Hill CE, Ryan EL, et al. Comparison of FilmArray and 
Quantitative Real-Time Reverse Transcriptase PCR for Detection of Zaire Ebolavirus from Contrived and Clinical Specimens. J Clin Microbiol. 2015; 53(9):2956-60.

60. Janvier F, Delaune D, Poyot T, Valade E, Merens A, Rollin PE, Foissaud V. Ebola Virus RNA Stability in Human Blood and Urine in West Africa's Environmental Conditions. Emerg Infect Dis. 2016;22(2):292-4.

61. Bodur H, Akinci E, Onguru P, Carhan A, Uyar Y, Tanrici A, Cataloluk O, Kubar A. Detection of Crimean-Congo hemorrhagic fever virus genome in saliva and urine. Int J Infect Dis. 2010;14(3):e247-9.

62. Thomas S, Thomson G, Dowall S, Bruce C, Cook N, Easterbrook L, O'Donoghue L, Summers S, Ajazaj L, Hewson R, et al. Review of Crimean Congo hemorrhagic fever infection in Kosova in 2008 and 2009: prolonged viremias and virus detected in urine by PCR. Vector Borne Zoonotic Dis. 2012;12(9):800-4.

63. Palacios G, Quan PL, Jabado OJ, Conlan S, Hirschberg DL, Liu Y, Zhai J, Renwick N, Hui J, Hegyi H, et al. Panmicrobial oligonucleotide array for diagnosis of infectious diseases. Emerg Infect Dis. 2007;13(1):73-81.

64. Boyd V, Smith I, Crameri G, Burroughs AL, Durr PA, White J, Cowled C, Marsh GA, Wang LF. Development of multiplexed bead arrays for the simultaneous detection of nucleic acid from multiple viruses in bat samples. J Virol Methods. 2015;223:5-12.

65. Zhang X, Liu Y, Zhao L, Li B, Yu H, Wen H, Yu XJ. An emerging hemorrhagic fever in China caused by a novel bunyavirus SFTSV. Sci China Life Sci. 2013; 56(8):697-700

66. Ding X, Wu X, Duan T, Siirin M, Guzman H, Yang Z, Tesh RB, Xiao SY Nucleotide and amino acid changes in West Nile virus strains exhibiting renal tropism in hamsters. Am J Trop Med Hyg. 2005;73(4):803-7.

67. Tesh RB, Siirin M, Guzman H, Travassos da Rosa AP, Wu X, Duan T, Lei H, Nunes MR, Xiao SY. Persistent West Nile virus infection in the golden hamster: studies on its mechanism and possible implications for other flavivirus infections. J Infect Dis. 2005;192(2):287-95.

68. Tonry JH, Xiao SY, Siirin M, Chen H, da Rosa AP, Tesh RB. Persistent shedding of West Nile virus in urine of experimentally infected hamsters. Am J Trop Med Hyg. 2005;72(3):320-4.

69. Steele KE, Linn MJ, Schoepp RJ, Komar N, Geisbert TW, Manduca RM, Calle PP, Raphael BL, Clippinger TL, Larsen T, et al. Pathology of fatal West Nile virus infections in native and exotic birds during the 1999 outbreak in New York City, New York. Vet Pathol. 2000;37(3):208-24.

70. Platt KB, Tucker BJ, Halbur PG, Blitvich BJ, Fabiosa FG, Mullin K, Parikh GR, Kitikoon P, Bartholomay LC, Rowley WA. Fox squirrels (Sciurus niger) develop West Nile virus viremias sufficient for infecting select mosquito species. Vector Borne Zoonotic Dis. 2008;8(2):225-33.

71. Platt KB, Tucker BJ, Halbur PG, Tiawsirisup S, Blitvich BJ, Fabiosa FG, Bartholomay $L C$, Rowley WA. West Nile virus viremia in eastern chipmunks (Tamias striatus) sufficient for infecting different mosquitoes. Emerg Infect Dis. 2007;13(6):831-7.

72. Saxena V, Xie G, Li B, Farris T, Welte T, Gong B, Boor P, Wu P, Tang SJ, Tesh $R$, et al. A hamster-derived West Nile virus isolate induces persistent renal infection in mice. PLoS Negl Trop Dis. 2013;7(6):e2275.

73. Tiawsirisup S, Blitvich BJ, Tucker BJ, Halbur PG, Bartholomay LC, Rowley WA, Platt KB. Susceptibility of fox squirrels (Sciurus niger) to West Nile virus by oral exposure. Vector Borne Zoonotic Dis. 2010;10(2):207-9.

74. Wu X, Lu L, Guzman H, Tesh RB, Xiao SY. Persistent infection and associated nucleotide changes of West Nile virus serially passaged in hamsters. J Gen Virol. 2008;89(Pt 12):3073-9.

75. Tonry JH, Brown CB, Cropp CB, Co JK, Bennett SN, Nerurkar VR, Kuberski T, Gubler DJ. West Nile virus detection in urine. Emerg Infect Dis. 2005;11(8):1294-6.

76. Murray K, Walker C, Herrington E, Lewis JA, McCormick J, Beasley DW, Tesh $\mathrm{RB}$, Fisher-Hoch S. Persistent infection with West Nile virus years after initial infection. J Infect Dis. 2010;201(1):2-4.

77. Barzon L, Pacenti M, Franchin E, Pagni S, Martello T, Cattai M, Cusinato R, Palu G. Excretion of West Nile virus in urine during acute infection. J Infect Dis. 2013;208(7):1086-92

78. Baty SA, Gibney KB, Staples JE, Patterson AB, Levy C, Lehman J, Wadleigh T, Feld J, Lanciotti R, Nugent $C T$, et al. Evaluation for West Nile Virus (WNV) RNA in urine of patients within 5 months of WNV infection. J Infect Dis. 2012;205(9):1476-7.

79. Gibney KB, Lanciotti RS, Sejvar JJ, Nugent CT, Linnen JM, Delorey MJ, Lehman JA, Boswell EN, Staples JE, Fischer M. West nile virus RNA not detected in urine of 40 people tested 6 years after acute West Nile virus disease. J Infect Dis. 2011;203(3):344-7.
80. Magurano F, Remoli ME, Baggieri M, Fortuna C, Marchi A, Fiorentini C, Bucci P, Benedetti E, Ciufolini MG, Rizzo C, et al. Circulation of West Nile virus lineage 1 and 2 during an outbreak in Italy. Clin Microbiol Infect. 2012; 18(12):E545-7.

81. Barzon L, Pacenti M, Franchin E, Squarzon L, Sinigaglia A, Ulbert S, Cusinato R, Palu G. Isolation of West Nile virus from urine samples of patients with acute infection. J Clin Microbiol. 2014;52(9):3411-3.

82. Barzon L, Pacenti M, Palu G. West Nile virus and kidney disease. Expert Rev Anti Infect Ther. 2013;11(5):479-87.

83. Barzon L, Pacenti M, Ulbert S, Palu G. Latest developments and challenges in the diagnosis of human West Nile virus infection. Expert Rev Anti Infect Ther. 2015;13(3):327-42.

84. Ergunay K, Karagul A, Abudalal A, Hacioglu S, Us D, Erdem Y, Ozkul A. Prospective investigation of the impact of West Nile Virus infections in renal diseases. J Med Virol. 2015;87(10):1625-32.

85. Nagy A, Ban E, Nagy O, Ferenczi E, Farkas A, Banyai K, Farkas S, Takacs M. Detection and sequencing of West Nile virus RNA from human urine and serum samples during the 2014 seasonal period. Arch Virol. 2016;161(7): 1797-806.

86. Papa A, Testa T, Papadopoulou E. Detection of West Nile virus lineage 2 in the urine of acute human infections. J Med Virol. 2014:86(12):2142-5.

87. Musso D. Zika Virus Transmission from French Polynesia to Brazil. Emerg Infect Dis. 2015;21(10):1887.

88. Musso D, Roche C, Nhan TX, Robin E, Teissier A, Cao-Lormeau VM. Detection of Zika virus in saliva. J Clin Virol. 2015;68:53-5.

89. Fourcade C, Mansuy JM, Dutertre M, Delpech M, Marchou B, Delobel P, Izopet J, Martin-Blondel G. Viral load kinetics of Zika virus in plasma, urine and saliva in a couple returning from Martinique, French West Indies. J Clin Virol. 2016;82:1-4

90. Zhang J, Jin X, Zhu Z, Huang L, Liang S, Xu Y, Liao R, Zhou L, Zhang Y, Wilder-Smith A. Early detection of Zika virus infection among travellers from areas of ongoing transmission in China. J Travel Med. 2016;23(5):1-3.

91. Dudley DM, Aliota MT, Mohr EL, Weiler AM, Lehrer-Brey G, Weisgrau KL, Mohns MS, Breitbach ME, Rasheed MN, Newman CM, et al. A rhesus macaque model of Asian-lineage Zika virus infection. Nat Commun. 2016;7: 12204.

92. Jang HC, Park WB, Kim UJ, Chun JY, Choi SJ, Choe PG, Jung SI, Jee Y, Kim NJ, Choi EH, et al. First Imported Case of Zika Virus Infection into Korea. J Korean Med Sci. 2016;31(7):1173-7.

93. Reusken C, Pas S, GeurtsvanKessel C, Mogling R, van Kampen J, Langerak T, Koopmans M, van der Eijk A, van Gorp E. Longitudinal follow-up of Zika virus RNA in semen of a traveller returning from Barbados to the Netherlands with Zika virus disease, March 2016. Euro Surveill. 2016;21(23): $1-4$.

94. D'Ortenzio E, Matheron S, Yazdanpanah Y, de Lamballerie X, Hubert B, Piorkowski G, Maquart M, Descamps D, Damond F, Leparc-Goffart I. Evidence of Sexual Transmission of Zika Virus. N Engl J Med. 2016;374(22): 2195-8.

95. Davidson A, Slavinski S, Komoto K, Rakeman J, Weiss D. Suspected Femaleto-Male Sexual Transmission of Zika Virus - New York City, 2016. MMWR Morb Mortal Wkly Rep. 2016;65(28):716-7.

96. Barzon L, Pacenti M, Berto A, Sinigaglia A, Franchin E, Lavezzo E, Brugnaro P, Palu G. Isolation of infectious Zika virus from saliva and prolonged viral RNA shedding in a traveller returning from the Dominican Republic to Italy, January 2016. Euro Surveill. 2016;21(10):1-5.

97. Bingham AM, Cone M, Mock V, Heberlein-Larson L, Stanek D, Blackmore C, Likos A. Comparison of Test Results for Zika Virus RNA in Urine, Serum, and Saliva Specimens from Persons with Travel-Associated Zika Virus Disease Florida, 2016. MMWR Morb Mortal Wkly Rep. 2016;65(18):475-8.

98. Bonaldo MC, Ribeiro IP, Lima NS, Dos Santos AA, Menezes LS, da Cruz SO, de Mello IS, Furtado ND, de Moura EE, Damasceno L, et al. Isolation of Infective Zika Virus from Urine and Saliva of Patients in Brazil. PLoS Negl Trop Dis. 2016;10(6):e0004816.

99. Grischott F, Puhan M, Hatz C, Schlagenhauf P. Non-vector-borne transmission of Zika virus: A systematic review. Travel Med Infect Dis. 2016; 14(4):313-30.

100. Leao JC, Gueiros LA, Lodi G, Robinson NA, Scully C. Zika virus: oral healthcare implications. Oral Dis. 2017;23(1):12-7.

101. Olson CK, Iwamoto M, Perkins KM, Polen KN, Hageman J, Meaney-Delman D, Igbinosa II, Khan S, Honein MA, Bell M, et al. Preventing Transmission of Zika Virus in Labor and Delivery Settings Through Implementation of 
Standard Precautions - United States, 2016. MMWR Morb Mortal Wkly Rep. 2016;65(11):290-2.

102. Scully C, Robinson A. Check before you travel: Zika virus--another emerging global health threat. Br Dent J. 2016;220(5):265-7.

103. Siqueira WL, Moffa EB, Mussi MC, Machado MA. Zika virus infection spread through saliva--a truth or myth? Braz Oral Res. 2016;30:1-2.

104. Domingo C, Yactayo S, Agbenu E, Demanou M, Schulz AR, Daskalow K, Niedrig M. Detection of yellow fever 17D genome in urine. J Clin Microbiol. 2011:49(2):760-2.

105. Martinez MJ, Vilella A, Pumarola T, Roldan M, Sequera VG, Vera I, Hayes EB, Persistence of yellow fever vaccine RNA in urine. Vaccine. 2011;29(18):33746.

106. Peiris JS, Chu CM, Cheng VC, Chan KS, Hung IF, Poon LL, Law KI, Tang BS, Hon TY, Chan CS, et al. Clinical progression and viral load in a community outbreak of coronavirus-associated SARS pneumonia: a prospective study. Lancet. 2003;361(9371):1767-72.

107. Wang WK, Chen SY, Liu IJ, Chen YC, Chen HL, Yang CF, Chen PJ, Yeh SH, Kao CL, Huang LM, et al. Detection of SARS-associated coronavirus in throat wash and saliva in early diagnosis. Emerg Infect Dis. 2004;10(7):1213-9.

108. Drosten C, Chiu LL, Panning M, Leong HN, Preiser W, Tam JS, Gunther S, Kramme S, Emmerich P, Ng WL, et al. Evaluation of advanced reverse transcription-PCR assays and an alternative PCR target region for detection of severe acute respiratory syndrome-associated coronavirus. J Clin Microbiol. 2004;42(5):2043-7.

109. Cheng VC, Hung IF, Tang BS, Chu CM, Wong MM, Chan KH, et al. Viral replication in the nasopharynx is associated with diarrhea in patients with severe acute respiratory syndrome. Clin Infect Dis. 2004;38(4):467-75.

110. Chan PK, To WK, Ng KC, Lam RK, Ng TK, Chan RC, Wu A, Yu WC, Lee N, Hui DS, et al. Laboratory diagnosis of SARS. Emerg Infect Dis. 2004;10(5):825-31.

111. Chu CM, Poon LL, Cheng VC, Chan KS, Hung IF, Wong MM, Chan KH, Leung WS, Tang BS, Chan VL, et al. Initial viral load and the outcomes of SARS. CMAJ. 2004;171(11):1349-52.

112. Hung IF, Cheng VC, Wu AK, Tang BS, Chan KH, Chu CM, et al. Viral loads in clinical specimens and SARS manifestations. Emerg Infect Dis. 2004;10(9): 1550-7.

113. Chu CM, Cheng VC, Hung IF, Chan KS, Tang BS, Tsang TH, Chan KH, Yuen KY. Viral load distribution in SARS outbreak. Emerg Infect Dis. 2005;11 (12):1882-6.

114. Mahony JB, Petrich A, Louie L, Song X, Chong S, Smieja M, Chernesky M, Loeb M, Richardson S. Ontario Laboratory Working Group for the Rapid Diagnosis of Emerging I: Performance and Cost evaluation of one commercial and six in-house conventional and real-time reverse transcription-pcr assays for detection of severe acute respiratory syndrome coronavirus. J Clin Microbiol. 2004;42(4):1471-6.

115. Lau SK, Che XY, Woo PC, Wong BH, Cheng VC, Woo GK, Hung IF, Poon RW, Chan KH, Peiris JS, et al. SARS coronavirus detection methods. Emerg Infect Dis. 2005;11(7):1108-11.

116. Wong SC, Chan JK, Lee KC, Lo ES, Tsang DN. Development of a quantitative assay for SARS coronavirus and correlation of GAPDH mRNA with SARS coronavirus in clinical specimens. J Clin Pathol. 2005;58(3):276-80.

117. Xu D, Zhang Z, Jin L, Chu F, Mao Y, Wang H, Liu M, Wang M, Zhang L, Gao GF, et al. Persistent shedding of viable SARS-CoV in urine and stool of SARS patients during the convalescent phase. Eur J Clin Microbiol Infect Dis. 2005; 24(3):165-71.

118. Wang XW, Li JS, Guo TK, Zhen B, Kong QX, Yi B, Li Z, Song N, Jin M, Wu XM, et al. Excretion and detection of SARS coronavirus and its nucleic acid from digestive system. World J Gastroenterol. 2005;11(28):4390-5.

119. Goffard A, Lazrek M, Schanen C, Lobert PE, Bocket L, Dewilde A, Hober D. Emergent viruses: SARS-associate coronavirus and H5N1 influenza virus. Ann Biol Clin (Paris). 2006;64(3):195-208.

120. Normile D. Second Lab Accident Fuels Fears About SARS. Science. 2004; 303(5654):26. https://doi.org/10.1126/science.303.5654.26.

121. Donaldson EF, Haskew AN, Gates JE, Huynh J, Moore CJ, Frieman MB. Metagenomic analysis of the viromes of three North American bat species: viral diversity among different bat species that share a common habitat. J Virol. 2010;84(24):13004-18.

122. Liu L, Wei Q, Alvarez X, Wang H, Du Y, Zhu H, Jiang H, Zhou J, Lam P, Zhang $L$, et al. Epithelial cells lining salivary gland ducts are early target cells of severe acute respiratory syndrome coronavirus infection in the upper respiratory tracts of rhesus macaques. J Virol. 2011;85(8):4025-30.

123. Lu B, Huang Y, Huang L, Li B, Zheng Z, Chen Z, Chen J, Hu Q, Wang H. Effect of mucosal and systemic immunization with virus-like particles of severe acute respiratory syndrome coronavirus in mice. Immunology. 2010; 130(2):254-61.

124. Drosten C, Seilmaier M, Corman VM, Hartmann W, Scheible G, Sack S, Guggemos W, Kallies R, Muth D, Junglen S, et al. Clinical features and virological analysis of a case of Middle East respiratory syndrome coronavirus infection. Lancet Infect Dis. 2013;13(9):745-51.

125. Eckerle I, Muller MA, Kallies S, Gotthardt DN, Drosten C. In-vitro renal epithelial cell infection reveals a viral kidney tropism as a potential mechanism for acute renal failure during Middle East Respiratory Syndrome (MERS) Coronavirus infection. Virol J. 2013;10:359.

126. Goh GK, Dunker AK, Uversky V. Prediction of Intrinsic Disorder in MERS-CoV/ HCoV-EMC Supports a High Oral-Fecal Transmission. PLoS Curr. 2013;5:1223.

127. Omrani AS, Al-Tawfiq JA, Memish ZA. Middle East respiratory syndrome coronavirus (MERS-CoV): animal to human interaction. Pathog Glob Health. 2015;109(8):354-62.

128. Corman VM, Olschlager S, Wendtner CM, Drexler JF, Hess M, Drosten C. Performance and clinical validation of the RealStar MERS-CoV Kit for detection of Middle East respiratory syndrome coronavirus RNA. J Clin Virol. 2014;60(2):168-71.

129. Cha RH, Joh JS, Jeong I, Lee JY, Shin HS, Kim G, Kim Y. Critical Care Team of National Medical C: Renal Complications and Their Prognosis in Korean Patients with Middle East Respiratory Syndrome-Coronavirus from the Central MERS-CoV Designated Hospital. J Korean Med Sci. 2015;30(12):180714.

130. Al-Tawfiq JA, Memish ZA. Managing MERS-CoV in the healthcare setting. Hosp Pract (1995). 2015;43(3):158-63.

131. Corman VM, Albarrak AM, Omrani AS, Albarrak MM, Farah ME, Almasri M, Muth D, Sieberg A, Meyer B, Assiri AM, et al. Viral Shedding and Antibody Response in 37 Patients With Middle East Respiratory Syndrome Coronavirus Infection. Clin Infect Dis. 2016;62(4):477-83.

132. Gossner C, Danielson N, Gervelmeyer A, Berthe F, Faye B, Kaasik Aaslav K, Adlhoch C, Zeller H, Penttinen P, Coulombier D. Human-Dromedary Camel Interactions and the Risk of Acquiring Zoonotic Middle East Respiratory Syndrome Coronavirus Infection. Zoonoses Public Health. 2016;63(1):1-9.

133. Du Y, Hughes RA, Bhadra S, Jiang YS, Ellington AD, Li B. A Sweet Spot for Molecular Diagnostics: Coupling Isothermal Amplification and Strand Exchange Circuits to Glucometers. Sci Rep. 2015;5:11039.

134. Abd El Wahed A, Patel P, Heidenreich D, Hufert FT, Weidmann M. Reverse transcription recombinase polymerase amplification assay for the detection of middle East respiratory syndrome coronavirus. PLoS Curr. 2013;5:1-6.

135. Yellow Fever laboratory diagnostic testing algorithm for Africa - Interim guidance- http://apps.who.int/iris/bitstream/10665/246226/1/WHO-OHE-YFLAB-16.1-eng.pdf. July 2016.

136. Fulhorst CF, Ksiazek TG, Peters CJ, Tesh RB. Experimental infection of the cane mouse Zygodontomys brevicauda (family Muridae) with guanarito virus (Arenaviridae), the etiologic agent of Venezuelan hemorrhagic fever. J Infect Dis. 1999;180(4):966-9.

137. Corman V, Kallies R, Philipps H, Göpner G, Müller MA, Eckerle I, et al. Characterization of a Novel Betacoronavirus Related to Middle East Respiratory Syndrome Coronavirus in European Hedgehogs. J of Virol. 2014; 88(1):717-24.

138. Poissy J. A.Goffard, E.Parmentier-Decrucq, R.Favory, M.Kauv, E.Kipnis, et al: Kinetics andpatternofviralexcretioninbiologicalspecimensoftwo MERS-CoV cases. JCV. 2014;61:275-8.

139. Her Z, Malleret B, Chan M, Ong EK, Wong SC, Kwek DJ, et al. Active infection of human blood monocytes by Chikungunya virus triggers an innate immune response. J Immunol. 2010;184(10):5903-13.

140. Reddy V, Mani RS, Desai A, Ravi V. Correlation of plasma viral loads and presence of Chikungunya IgM antibodies with cytokine/chemokine levels during acute Chikungunya virus infection. J Med Virol. 2014;86(8):1393-401.

141. Parida MM, Santhosh SR, Dash PK, Tripathi NK, Lakshmi V, Mamidi N, et al. Rapid and real-time detection of Chikungunya virus by reverse transcription loop-mediated isothermal amplification assay. J Clin Microbiol. 2007;45(2): $351-7$.

142. Lewthwaite P, Vasanthapuram R, Osborne JC, Begum A, Plank JL, Shankar $M V$, et al. Chikungunya virus and central nervous system infections in children, India. Emerg Infect Dis. 2009;15(2):329-31.

143. Klungthong C, Gibbons RV, Thaisomboonsuk B, Nisalak A, Kalayanarooj S, Thirawuth $\mathrm{V}$, et al. Dengue virus detection using whole blood for reverse transcriptase PCR and virus isolation. J Clin Microbiol. 2007;45(8):2480-5. 
144. Srikiatkhachorn A, Wichit S, Gibbons RV, Green S, Libraty DH, Endy TP, et al. Dengue viral RNA levels in peripheral blood mononuclear cells are associated with disease severity and preexisting dengue immune status. PLoS One. 2012;7(12):e51335.

145. Solomon T, Dung NM, Vaughn DW, Kneen R, Thao LT, Raengsakulrach B, et al. Neurological manifestations of dengue infection. Lancet. 2000;355(9209): 1053-9.

146. Barthel A, Gourinat AC, Cazorla C, Joubert C, Dupont-Rouzeyrol M, Descloux E. Breast milk as a possible route of vertical transmission of dengue virus? Clin Infect Dis. 2013;57(3):415-7.

147. Rios M, Daniel S, Chancey C, Hewlett IK, Stramer SL. West Nile virus adheres to human red blood cells in whole blood. Clin Infect Dis. 2007;45(2):181-6.

148. Lanteri MC, Lee TH, Wen L, Kaidarova Z, Bravo MD, Kiely NE, et al. West Nile virus nucleic acid persistence in whole blood months after clearance in plasma: implication for transfusion and transplantation safety. Transfusion. 2014;54(12):3232-41.

149. Tilley PA, Fox JD, Jayaraman GC, Preiksaitis JK. Nucleic acid testing for west nile virus RNA in plasma enhances rapid diagnosis of acute infection in symptomatic patients. J Infect Dis. 2006;193(10):1361-4.

150. Tyler KL, Pape J, Goody RJ, Corkill M, Kleinschmidt-DeMasters BK. CSF findings in 250 patients with serologically confirmed West Nile virus meningitis and encephalitis. Neurology. 2006;66(3):361-5.

151. Hinckley AF, O'Leary DR, Hayes EB. Transmission of West Nile virus through human breast milk seems to be rare. Pediatrics. 2007;119(3):e666-71.

152. Domingo C, Patel P, Yillah J, Weidmann M, Mendez JA, Nakoune ER, et al. Advanced yellow fever virus genome detection in point-of-care facilities and reference laboratories. J Clin Microbiol. 2012;50(12):4054-60.

153. Traiber C, Coelho-Amaral P, Ritter VR, Winge A. Infant meningoencephalitis caused by yellow fever vaccine virus transmitted via breastmilk. J Pediatr (Rio J). 2011;87(3):269-72.

154. Chaves M, Riccio P, Patrucco L, Rojas Jl, Cristiano E. Longitudinal myelitis associated with yellow fever vaccination. J Neurovirol. 2009;15(4):348-50.

155. Noronha L, Zanluca C, Azevedo ML, Luz KG, Santos CN. Zika virus damages the human placental barrier and presents marked fetal neurotropism. Mem Inst Oswaldo Cruz. 2016;111(5):287-93.

156. Roze B, Najioullah F, Signate A, Apetse K, Brouste Y, Gourgoudou S, et al. Zika virus detection in cerebrospinal fluid from two patients with encephalopathy, Martinique, February 2016. Euro Surveill. 2016;21(16):1-4.

157. Swaminathan S, Schlaberg R, Lewis J, Hanson KE, Couturier MR. Fatal Zika Virus Infection with Secondary Nonsexual Transmission. N Engl J Med. 2016; 375(19):1907-9.

158. Calvet G, Aguiar RS, Melo AS, Sampaio SA, de Filippis I, Fabri A, et al. Detection and sequencing of Zika virus from amniotic fluid of fetuses with microcephaly in Brazil: a case study. Lancet Infect Dis. 2016;16(6):653-60.

159. Dupont-Rouzeyrol M, Biron A, O'Connor O, Huguon E, Descloux E. Infectious Zika viral particles in breastmilk. Lancet. 2016;387(10023):1051.

160. Towner JS, Rollin PE, Bausch DG, Sanchez A, Crary SM, Vincent M, et al. Rapid diagnosis of Ebola hemorrhagic fever by reverse transcription-PCR in an outbreak setting and assessment of patient viral load as a predictor of outcome. J Virol. 2004;78(8):4330-41.

161. Sow MS, Etard JF, Baize S, Magassouba N, Faye O, Msellati P, et al. New Evidence of Long-lasting Persistence of Ebola Virus Genetic Material in Semen of Survivors. J Infect Dis. 2016;214(10):1475-6.

162. Baggi FM, Taybi A, Kurth A, Van Herp M, Di Caro A, Wolfel R, et al. Management of pregnant women infected with Ebola virus in a treatment centre in Guinea, June 2014. Euro Surveill. 2014;19(49):1-4.

163. Jacobs M, Rodger A, Bell DJ, Bhagani S, Cropley I, Filipe A, et al. Late Ebola virus relapse causing meningoencephalitis: a case report. Lancet. 2016; 388(10043):498-503.

164. Rowe AK, Bertolli J, Khan AS, Mukunu R, Muyembe-Tamfum JJ, Bressler D, et al. Clinical, virologic, and immunologic follow-up of convalescent Ebola hemorrhagic fever patients and their household contacts, Kikwit, Democratic Republic of the Congo. Commission de Lutte contre les Epidemies a Kikwit. J Infect Dis. 1999;179(Suppl 1):S28-35.

165. Ng LF, Wong M, Koh S, Ooi EE, Tang KF, Leong HN, et al. Detection of severe acute respiratory syndrome coronavirus in blood of infected patients. J Clin Microbiol. 2004;42(1):347-50.

166. Wang H, Mao Y, Ju L, Zhang J, Liu Z, Zhou X, et al. Detection and monitoring of SARS coronavirus in the plasma and peripheral blood lymphocytes of patients with severe acute respiratory syndrome. Clin Chem. 2004;50(7):1237-40.
167. Wang YD, Li Y, Xu GB, Dong XY, Yang XA, Feng ZR, et al. Detection of antibodies against SARS-CoV in serum from SARS-infected donors with ELISA and Western blot. Clin Immunol. 2004;113(2):145-50.

168. Hung EC, Chim SS, Chan PK, Tong YK, Ng EK, Chiu RW, et al. Detection of SARS coronavirus RNA in the cerebrospinal fluid of a patient with severe acute respiratory syndrome. Clin Chem. 2003;49(12):2108-9.

169. Isakbaeva ET, Khetsuriani N, Beard RS, Peck A, Erdman D, Monroe SS, et al. SARS-associated coronavirus transmission, United States. Emerg Infect Dis. 2004;10(2):225-31

170. Kim SY, Park SJ, Cho SY, Cha RH, Jee HG, Kim G, et al. Viral RNA in Blood as Indicator of Severe Outcome in Middle East Respiratory Syndrome Coronavirus Infection. Emerg Infect Dis. 2016;22(10):1813-6.

171. Kim MN, Ko YJ, Seong MW, Kim JS, Shin BM, Sung H. Analytical and Clinical Validation of Six Commercial Middle East Respiratory Syndrome Coronavirus RNA Detection Kits Based on Real-Time Reverse-Transcription PCR. Ann Lab Med. 2016;36(5):450-6.

\section{Ready to submit your research? Choose BMC and benefit from:}

- fast, convenient online submission

- thorough peer review by experienced researchers in your field

- rapid publication on acceptance

- support for research data, including large and complex data types

- gold Open Access which fosters wider collaboration and increased citations

- maximum visibility for your research: over $100 \mathrm{M}$ website views per year

At $\mathrm{BMC}$, research is always in progress.

Learn more biomedcentral.com/submissions 